\title{
Strategic Planning Model of The Department Health in The Implementation Environmental Health Of New Normal Era In Serang City
}

\author{
Rina Yulianti ${ }^{1}$, Ipah Ema Jumiati ${ }^{2}$ \\ Sultan Ageng Tirtayasa University ${ }^{12}$ \\ \{rina.yulianti@untirta.ac.id\}
}

\begin{abstract}
Environmental health is the realization of an ecological balance between humans and the environment that must exist, so that people become healthy and prosperous. The Serang City Health Office, which is responsible for environmental health issues, must have a more appropriate strategic planning in the implementation of environmental health in the era of adaptation of new habits. Based on initial observations, there are problems that occur related to environmental health, namely people who do not use clean water, especially in Kasemen District, and residents who do not have basic sanitation ownership in Serang City and lack of government supervision on the importance of environmental health in Serang City. Adaptation to New Era is a community effort to adapt to the environment, in the form of changing self-behavior to be more disciplined, maintaining cleanliness, and obeying health protocol regulations. Environmental health plays an important role in adapting new era, because a healthy environment slows down the spread of Covid-19. The approach used is qualitative with the research method used is descriptive analytical, which seeks to describe and provide an explanation of the strategic planning of the Department of Health in the implementation of environmental health in Serang City. The results of this study are that the strategic planning of the Department of Health in the implementation of environmental health in the era of adaptation of new era in Serang City has been carried out but has not been maximized, because the facilities and infrastructure are not yet equipped. In addition, the Serang City Health Office must be stronger in collaborating with other parties so that synergy is established in creating a clean environment, so that the decline in COVID-19 is accompanied by the readiness of the community to change their lifestyle. The recommendation of this research is to encourage people to behave in a clean life, to socialize the importance of maintaining environmental health and to increase official collaboration with various cross-sectoral stakeholders.
\end{abstract}

Keywords: Strategic Planning, Environmental Health, Adaptation of New Era

\section{Introduction}

Health is a human right and one of the elements of welfare that must be realized and fulfilled. In the 1945 Constitution of the Republic of Indonesia Article 28 A states that everyone has the right to live and live. According to the regulation, the right to live and maintain one's life is closely related to health as one of the basic human needs and elements of human welfare. Health according to the World Health Organization (WHO) is a state of complete physical, mental and social well-being, not only free from disease and infirmity.

According to WHO (World Health Organization 2005) Environmental health is the realization of an ecological balance between humans and the environment that must exist, so that people become healthy and prosperous. It can also be concluded that an ecological balance 
must exist between humans and the environment in order to ensure the healthy state of humans. The environment is one of the determinants of health status, in addition to several other variables such as behavior, the existence of health services. Environmental health is an important factor in human life in social life, in fact it is one of the determining elements or determinants in the welfare of the population. In the future, the government will focus more on implementing sustainable development and environmentally conscious regional development, while the infrastructure users, in this case the community, must be prepared with better awareness. Environmental health problems are complex problems that require integration from various related sectors to overcome them.

Health development in Serang City aims to increase awareness, willingness, and ability to live healthy for every citizen in order to realize the highest degree of health, marked by residents who behave in a clean and healthy life and live in a healthy environment, and have the ability to reach quality health services in a fair and equitable manner throughout the city of Serang. To achieve this goal, health development is carried out by the city government, the community, and the private sector. The Banten Province Health Profile in 2018 which describes that the number of Households with Clean and Healthy Living Behavior in Serang City reaches $66.1 \%$ (Serang City Health Office 2018).

Thus, the Serang City Health Office, which is responsible for environmental health problems, must have a more appropriate strategy in health management so that the public gets education about environmental health and can also minimize existing problems. From the initial observations that the researchers made, there were several problems related to environmental health that occurred in Serang City, as follows:

First, the lack of government oversight of environmental health in Serang City is because there are still many people who have uninhabitable houses and do not fall into the category of healthy home ownership or clean-living behavior, especially in the Kasemen District. Serang City itself is fairly large number of residents who do not have a healthy home ownership requirement, namely in Serang City in 2016 from 121,696 houses there were 38,906 healthy houses (32.0\%). In 2017 from 123,074 houses there were 44,155 healthy houses $(35.9 \%)$. In 2018 from 117,315 houses there were 54,552 healthy houses (46.50\%). It can be seen from the table recap of healthy homes in 2018 .

Second, the lack of socialization from the Serang City Health Office regarding environmental health is due to the fact that there are still some people who do not use clean water. In the daily life of the people in Serang City, there are still many who use or utilize river/irrigation water to fulfill their needs such as for washing, bathing, and washing other household equipment, some even drink water from the river just for drinking.

Third, the limited facilities and infrastructure for trash bins and public toilets because there are still many people who do not have ownership of basic sanitation facilities in Serang City which include ownership of latrines, ownership of trash bins and also ownership of waste water disposal. Based on table 1.2, the population of Serang City in 2018 was 666,600 people, residents with access to proper sanitation were 219,134 or $34.47 \%$, of which less than $50 \%$ of people who had access to proper sanitation had healthy latrines.

To combat Covid-19, the City of Serang has implemented various environmental and social health security measures (PHSM/PSBB), including limiting large-scale population movements, closing schools and offices, regional quarantine and restricting travel between countries. Adaptation to new era is a community effort to adapt to the environment, in the form of changing self-behavior to be more disciplined, maintaining cleanliness, and obeying health protocol regulations. So that people stay productive while staying safe from Covid-19. 
Environmental health plays an important role in adapting new era to fight Covid-19 because a healthy environment slows down the spread of Covid-19.

\section{Discussion}

Environmental health is a very important aspect in life, where environmental health greatly affects the survival of the people who occupy it, because it has a very important role, the local government asks the Health Office to pay more attention to environmental health in Serang City. STBM Program (Community-Based Total Sanitation) is a program that is aimed at empowering the community. The program also triggers the strength of the Serang City Health Office, where the STBM program is issued by the Ministry of Health which is a national strategy to improve and empower the community.

Community Based Total Sanitation (STBM) is an approach to change hygiene and sanitation behavior through community empowerment with the triggering method. STBM program has outcome and output indicators. The STBM outcome indicator is a decrease in the incidence of diarrheal disease and other environmental-based diseases related to sanitation and behavior.

While the STBM output indicators are as follows: 1. Every individual and community have access to basic sanitation facilities so that they can create a community that is free from open defecation (ODF). 2. Every household has implemented safe drinking water and food management in the household. 3. Every household and public service facilities in a community (such as schools, offices, restaurants, health centers, markets, terminals) are provided with hand washing facilities (water, soap, hand washing facilities), so that everyone washes their hands properly. 4. Every household manages its waste properly. 5. Every household manages its waste properly.

This triggering method is very useful for the community, especially to provide more awareness of the importance of maintaining health. Moreover, during this pandemic, maintaining immunity is very important so as not to be easily exposed to the virus, by maintaining health protocols and also maintaining environmental cleanliness so as not to add to the epidemic for the community.

\section{Strategy of the Department of Health in the Implementation of Environmental Health in the Era of Pandemic Adaptation}

According to Ralston, B and Wilson, I (2006: 144) the elements in a strategy are: concept, program, resources, monitoring and response, and finally the next step. Based on this opinion, it is known that a strategy must be comprehensive or holistic which includes elements of the organization's internal and external environment, monitoring and controlling them. Then it can be identified that the elements of the strategy above are important to achieve the goals and targets of the organization.

The strategy will run if all the elements that exist can be united. Support each other and can make a big contribution in the organization. The health office has tried to do its job of assisting the government in implementing environmental health in Serang City. Environmental health is one of the important aspects in human life, because environmental health greatly affects the survival of humans who inhabit it. Environmental health has a very important role, therefore environmental health must of course be a special concern in order to realize optimal environmental health conditions. If the health of the environment is good, the health of the people will be good and vice versa if in a place the health condition of the environment is still low, then the health of the people will be low. 
In this case the Health Office as the OPD in charge of environmental health affairs and has an environmental health section, the Serang City Health Office, has carried out its duties in implementing environmental health, which leads to triggering where the main focus is changing the behavior of people who are aware of the environment so as to improve health status. public. And encourage people to be aware and care about environmental health. The triggering carried out by the health office aims to form public awareness to be more concerned with environmental health and to form community independence in protecting their environment. Community participation is very influential in change and awareness which will later become good behavior.

During a pandemic, the health system is faced with maintaining a balance between meeting the needs of dealing with the pandemic and meeting essential health services. This balance must be maintained so that there will not be an increase in cases of other diseases after this pandemic. In the Minister of Health Regulation Number 43 of 2019 concerning Community Health Centers, it is stated that district/city regional health offices have a working relationship with Community Health Centers that are coaching.

Guidance is carried out by the district/city health office to the Puskesmas as a technical implementing unit that has autonomy in the context of synchronizing and harmonizing the achievement of regional health development goals. The achievement of regional health development goals is part of the duties, functions, and responsibilities of the district/city health office. The provincial health office as an extension of the central government is expected to provide guidance to the district/city regional health office through the development of programs carried out in stages. The roles of district/city health offices and provincial health offices in Puskesmas services during the COVID-19 pandemic are as follows:

\section{District/City Health Office:}

a. Ensure the continuity of the availability of Puskesmas resources during the COVID-19 pandemic according to standards, in ensuring the quality of services.

b. Ensure the continuity of the availability of operational funds and maintenance of facilities, infrastructure, equipment and calibration of Puskesmas equipment during the COVID-19 pandemic.

c. Improve the competence of Puskesmas personnel during the COVID-19 pandemic.

d. Monitoring and evaluating the performance of the Puskesmas during the COVID-19 pandemic in its working area on a regular and continuous basis.

e. Conducting technical guidance in an integrated manner between health programs implemented at the Puskesmas during the COVID-19 pandemic.

f. Provide solutions to problems that cannot be resolved at the Puskesmas during the COVID19 pandemic.

g. Support the development of health efforts in the work area of the Puskesmas during the COVID-19 pandemic.

h. Issue regulations that aim to facilitate improving access and quality of services during the COVID-19 pandemic.

i. Issue district/city-level operational policies related to COVID-19, such as: a. The handling scheme if there are Puskesmas officers or human resources who are affected by COVID-19 and tracking is carried out and the results need to be quarantined/isolated for close contacts, then based on the analysis carried out, is it necessary to close the Puskesmas because officers must carry out self-isolation for 14 days or the Puskesmas remains open with temporarily mobilizing officers/HR from other Puskesmas or requesting support from other FKTP or volunteer recruitment. The thing that becomes the basis for consideration is how the community can still be served. b. Schemes for outdoor activities and home visits such as 
PIS-PK, Posyandu, and other UKBM activities during the COVID-19 pandemic. c. The use of telemedicine in the form of teleconsultation to minimize contact between the community/patients and health workers at the Puskesmas.

j. Facilitating cross-program integration related to health and the profession in terms of planning, implementing and evaluating the implementation of the Puskesmas program during the Covid-19 pandemic.

k. Coordination with cross-sectors at the district/city level.

1. Submit reports on activities, data and priority health problems at the Puskesmas during the COVID-19 pandemic in districts/cities periodically to the provincial health office.

Furthermore, strengthening the role of sub-district offices and village village offices for community empowerment in handling Covid-19. The optimization that needs to be done is the equipment of human resource instruments for public health units such as puskesmas. The strength of our national health system is currently being tested along with the escalation of COVID-19 cases that have hit all provinces in Indonesia. Health care facilities are at the forefront of dealing with health problems in the community due to COVID-19. The health center, which has been the spearhead of health services to reach the community in its working area, has an increasingly important role in handling COVID-19, not to mention Serang City, Banten province.

The role of the puskesmas needs to be strengthened in terms of prevention, namely efforts that aim to reduce or prevent the risk of the impact of social change with the presence of covid19, detection and response in accordance with their authority as first-level health service facilities. But on the other hand, the Puskesmas also has the task and function of carrying out public health efforts and individual health efforts in the context of meeting minimum service standards for the community which should not be abandoned during this pandemic. The health center is the front line in breaking the chain of transmission of COVID-19 because it is located in every sub-district and has a regional concept. In the condition of the COVID-19 pandemic, efforts to handle, prevent and limit the transmission of infection by the health center are needed.

Although this has become a priority, it does not mean that the Puskesmas can leave other services that are the functions of the Puskesmas, namely carrying out the first-level Community Health Efforts (UKM) and Individual Health Efforts (UKP) as stipulated in the Minister of Health Regulation Number 43 of 2019 concerning Community Health Centers (Puskesmas).

The city of Serang has as many as 16 Puskesmas which are health service facilities that organize public health efforts and first-level individual health efforts, by prioritizing promotive and preventive efforts, to achieve the highest degree of public health. These health efforts are carried out with an emphasis on services for the wider community in order to achieve optimal health degrees, without neglecting the quality of services to individuals. The Puskesmas is led by a head of the Puskesmas who is responsible to the District/City Health Office as shown in the table below:

Table 1. Community Health Centers in Serang City

\begin{tabular}{|c|c|c|c|}
\hline & & \multicolumn{2}{|c|}{ Community Health Centers in Serang City } \\
\cline { 3 - 4 } No & Name of Districts & $\mathbf{2 0 1 9}$ & $\mathbf{2 0 2 0}$ \\
\hline 1 & Curug & 1 & 1 \\
\hline 2 & Walantaka & 2 & 2 \\
\hline 3 & Cipocok Jaya & 3 & 3 \\
\hline 4 & Serang & 5 & 5 \\
\hline 5 & Taktakan & 2 & 2 \\
\hline 6 & Kasemen & 4 & 3 \\
\hline
\end{tabular}




\begin{tabular}{|c|c|c|}
\hline Jumlah & 17 & 16 \\
\hline
\end{tabular}

Source : Serang City in Numbers (BPS, 2020).

With the Puskesmas so that there are health workers to support the work in Serang City. Health worker is every person who devotes himself to the health sector and has knowledge and/or skills through education in the health sector which for certain types requires the authority to carry out health efforts. The Puskesmas helps a lot in administering vaccines and socializing the importance of the community to maintain immunity.

Socialization to the community carried out by the Serang City Health Office in various kinds of activities is the main target in order to increase the coverage and participation of the community in the implementation of environmental health, including:socialization of the importance of environmental health to the community whose targets are community leaders, religious leaders, cadres, and posyandu.

\section{New Habit Adaptation}

Indonesian people are required to live with a new order of life, which can 'make peace' with COVID-19. What is meant by New Normal is an action or behavior carried out by the community and all institutions in the area to carry out daily patterns or new work patterns or lifestyles that are different from before. If this is not done, there will be a risk of transmission. The purpose of the New Normal is to keep people productive and safe from Covid-19 at this time. Furthermore, so that the New Normal is more easily internalized by the community, "New Normal" is narrated as "Adaptation of New Habits". The purpose of Adapting New Habits is so that we can work, study and do activities productively in the era of the Covid-19 Pandemic. New habits for a healthier life must be continuously carried out in society and every individual, so that it becomes a new social norm and individual norm in everyday life.

More than 200 countries have also felt the impact of the virus which has claimed more than 657,266 lives worldwide (data as of July 28,2020 ). Noting this, the government has finally begun to implement a new life adaptation in the midst of controlling this Covid-19, not only aiming to restore the economic sector, but also to provide good health services in the midst of control.

Discipline in implementing health protocols can reduce the spread of COVID-19. But is there a guarantee that all the health protocols that have been regulated can run well and in an orderly manner? Who dares to guarantee that all managers/organizers, traders/business actors, workers/employees, visitors/guests/consumers/passengers/community can comply with the implementation of all health protocols? Instruments of strict supervision and control must inevitably be regulated. The Health Office has provided technical instructions for the health protocol, but it is not enough. Community involvement in supervision is one of the best options.

Covid-19 Pandemic until now, it is still uncertain how long it will last until we find a formula/vaccine that can really kill this virus and the vaccine can be used on everyone until optimal immunity occurs. New normal itself has been echoed in all sectors. The local government of Serang City, especially the Serang City Health Service, is taking steps in implementing environmental health in this era of adapting to new habits. As described in the background of the problem, there are still problems related to environmental health, in which there are still uninhabitable houses and water cleanliness.

In this pandemic period, of course, there are many challenges that must be faced in providing counseling and follow-up to the community. Therefore, the Health Office invites puskesmas and posyandu in Serang City to be even more active in providing counseling to the community so that they can adapt to new things that cannot be done during the pre-pandemic 
period. In this new normal era, puskesmas must go directly to remind residents in their area to always comply with health protocols. Every time they carry out activities outside their homes, people are asked to always wear masks even though the number of Covid patients has decreased, meaning that people are asked to always maintain health and cleanliness in their respective neighborhoods.

\section{Conclusion}

The strategic planning of the Department of Health in the implementation of environmental health in the New Habit Adaptation Era in Serang City has been carried out, but it has not been maximized, because the facilities and infrastructure are not yet equipped in the era of adapting new habits. Giving vaccines and maintaining health protocols is very important for the community. Strategic steps need to be taken so that new habits during this pandemic can protect people from various existing diseases. The Serang City Health Office must be stronger in collaborating with other parties so that there is synergy in creating a clean environment, so that the decline in COVID-19 is accompanied by the readiness of the community to change their lifestyle.

\section{Suggestion}

Based on the research results, there are several things that can be recommended: 1 . encourage people to behave in a clean life; 2. To socialize the importance of maintaining environmental health; 3 . Improving the cooperation of the service with various cross-sectoral stakeholders.

\section{References}

[1] Adnani, Harzina, 2018, Ilmu Kesehatan Masyarakat, Yogyakarta:Nuha Medika Yogyakarta.

[2] Bryson, J.M. 2007. Perencanaan Strategis Bagi Organisasi Sosial. Yogyakarta: Pustaka Pelajar.

[3] Bungin, Burhan. 2008. Penelitian Kualitatif, Komunikasi, Ekonomi, Kebijakan Publik, dan Ilmu Sosial Lainnya. Jakarta: Kencana Prenada Media Group.

[4] Mundiatun dan Daryanto, 2015, Pengelolaan Kesehatan Lingkungan, Yogjakarta:Penerbit Gava

[5] Salusu. 2005. Pengambilan Keputusan Stratejik: Untuk Organisasi Publik dan Organisasi Nonprofit. Jakarta: Grasindo.

[6] S. Cecep Dani dan Asmadi, 2011, Aspek Kesehatan Masyarakat Dalam Amdal, Yogjakarta:Gosyen

[7] Sumantri, Arif, 2010, Kesehatan Lingkungan \& Perspektif Islam, Jakarta:Prenada Media Group.

[8] Triwibowo, Cecep, 2014, Kesehatan Lingkungan dan K3, Yogjakarta:Nuha Medika.

[9] Dian K. Adaptasi Terhadap Kebiasaan Baru Panduan Kerja Sehat Aman Produktif Selama Masa Pandemi Covid 19. Di publis BKKBN. Di akses https://www.researchgate.net/publication/342804299, pada tanggal 26 November 2020.

[10] Website

[11] http://kesmas.kemkes.go.id/perpu/konten/pp/pp-no.-66.tentang-kesehatan-lingkungan-pdf (Diakses pada 26 November 2020)

[12] http://kesling.kesmas.kemkes.go.id/\# (Diakses pada 26 November 2020) 